\title{
Civil Disobedience and Cyber Democracy
}

\author{
Zawiyah Mohd Zain ${ }^{1}$ \\ Zaheruddin Othman ${ }^{1}$ \\ Zalinah Ahmad $^{1}$ \\ Mohd Fitri Abdul Rahman ${ }^{1}$ \\ Mohd Na'iem Ajis ${ }^{1}$ \\ Kamaruddin $\mathrm{Ngah}^{1}$ \\ Mohammad Agus Yusoff ${ }^{2}$

\begin{abstract}
${ }^{1}$ School of Government, College of Law, Government and International Studies,
Universiti Utara Malaysia, Malaysia Universiti Kebangsaan Malaysia, Malaysia
\end{abstract} \\ ${ }^{2}$ School of History, Politics and Strategy, Faculty of Social Sciences and Humanities
}

Doi: 10.1515/mjss-2017-0001

\begin{abstract}
The purpose of this paper is to analyze the emergence of civil disobedience in Malaysia specifically in the era of Abdullah Badawi, and its impact upon the democratization process. The whole analysis in this paper is qualitative and derived from two types of data which is primary and secondary data. The analysis shows that civil disobedience arose due to three factors, namely the government's failure to fulfill its promise to reform, Mahathir's criticism against Abdullah Badawi's leadership, and the government failure to handle racial issues. Consequently, Barisan Nasional (The National Front) government failed to gain two-thirds majority of the parliamentary seats in the 2008 general elections and at the same time lost five states to the opposition. In 2013 general election the result remain the same which is government failed to gain two-thirds majority of the parliamentary seats. Furthermore, even though the emergence of civil disobedience failed to create a change of government, it however has been able to give birth to cyber democracy and create awareness among Malaysians to pursue the process of democratization.
\end{abstract}

Keywords: Civil disobedience, cyber democracy, democratization, election, Internet.

\section{Introduction}

Civil disobedience has been in existence since the $18^{\text {th }}$ century. However it did not become a phenomenon until the $19^{\text {th }}$ century as civil disobedience was often used against government decision. The purpose of this paper is to examine the emergence of civil disobedience in Malaysia specifically during Abdullah Badawi's reign. The major questions to be explored here include: What are Abdullah Badawis's new policies? Did he implement policies that have been planned? What are the reasons that led to the emergence of civil disobedience? And what is the impact of civil disobedience on the democratization process? In order to answer these questions, this article divided into several parts: First, conceptual discussion on civil disobedience. Second, methodology part. Third, explains new policies introduced by Abdullah Badawi, discusses the emergence of civil 
disobedience in second phase of Abdullah Badawi's administration and analyze the impact of civil disobedience and the emergence of cyber democracy.

\section{Civil Disobedience Concept}

According to Rawls (1971) civil disobedience is public, nonviolent, conscientious yet political act contrary to law usually done with the aim of bringing about a change in the law or policies of the government. Rawls in his arguments state that first, civil disobedience is a political act not only in the sense that it is addressed to the majority that hold political power, but is also because it is an act guided and justified by political principle which is principle of justice. Second, civil disobedience is a public act, not only it is addressed to principles, it is done in public and not covert or secretive. Third, civil disobedience is nonviolent because it expresses disobedience to law within the limits of fidelity to law although it is at outer edge thereof. The law is broken, but fidelity to law is expresses by the public and nonviolent nature of the act, by the willingness to accept the legal consequences of one's conduct.

Quigley \& Bahmueller (1991), defines civil disobedience is a deliberate, public, conscientious, and nonviolent act that breaks a law in which the person accepts responsibility and punishment. It is an act of nonviolent protest undertaken to alleviate some injustice, usually with an appeal to some higher principle or law. Base on this definition, the act considered as civil disobedience is first, the citizen must disobey the law, most often the law that is being broken is considered unjust. Second, the citizen would have to deliberately and publicly disobey the law. The citizen must be acting to serve the common good, not the personal interest. Third, the citizen must act conscientiously, in that he or she has an honest belief that his or her actions are intended to correct a grave injustice. Finally, the act must be nonviolent and the citizen must be willing to accept the consequences of his or her action. Quigley \& Bahmueller also stress that there are two types of civil disobediences which are individual or moral disobedience and organized or social civil disobedience.

Briefly, according to the scholars there are several important features in civil disobedience act. First, disobedience of the law. Second, disobedience carried out in public because of frustration with government actions or unjust laws or policies. Third, non-violence acts. Fourth, the act must be conscientiously. Finally, people are willing to accept the consequences of their actions. There are two types of civil disobedience: moral disobedience which is by individual and social civil disobedience which is organized by a group. The examples of civil disobedience are the refusal to pay taxes, blocking roads to government offices, strikes and street demonstrations without government permission (Sheldon, 2005). In addition, civil disobedience may occur via the internet as people criticize and express their dissatisfaction to the government or its officers through blogs or social media. And the action aims to pressure the government to change unjust laws and policies.

\section{Method of the Study}

The whole analysis in this paper is qualitative and derived from two types of data. The primary data is generated through in-depth interviews with individuals who are experience and knowledgeable about the subjects under study. They are representative of the government political party which is Barisan Nasional (BN) (United Malay National Organization [UMNO], Malaysian Chinese Association [MCA] and Malayan Indian Congress [MIC]), opposition party (Parti Keadilan Rakyat [PKR], Parti Islam SeMalaysia [PAS]) and non-governmental organizations (Angkatan Belia Islam Malaysia [ABIM], PERKASA, Christian of Federation Malaysia [CFM]). The secondary data is obtained from books, journals, previous studies and documents from government departments.

\section{Finding and Discussion}

After Mahathir Mohamad resigned in 2003, his successor Abdullah Badawi promised to reform democratic governance and socio-economic policies. In order to reform democratic governance, he 
promised attractive changes. For instance, government has been focus in fighting corruption, eliminating the abuse of power in the government, reducing bureaucratic red tape, improving public services delivery, restoration of the judicial system and strengthening the enforcement agencies such as police agency (Marzuki Mohamad, 2004; Paridah Abdul Samad, 2008). In terms of economic, the government priority is on agriculture sector as key areas to increase economic growth. At the same time, to avoid wastage of public fund he had to stop mega projects. For example, half bridge or crooked bridge project linking Johor and Singapore that was planned during Mahathir's era was stopped.

Furthermore, by 2004, Malaysia's economic growth had increased. For example, on February 25, Central Bank announced that Gross Domestic Product (GDP) had increased by more than two percent of the expectations made of 4.5 percent. The growth was supported by consumer spending, increased exports in the manufacturing sector and an increase in investment. Malaysia also recorded higher earnings through a composite index on the Kuala Lumpur Stock Exchange (KLSE). On March 18, the composite index reached 900 points and closed at 901.48 which are the highest in four years (Abdul Rashid Moten \& Tunku Mohar Mokhtar, 2006).

Subsequently, after six months as Prime Minister (PM) Abdullah Badawi dissolved the Parliament on March 4, 2004 and the $11^{\text {th }}$ general elections was held on March 21. In this general election Barisan Nasional (BN) had a variety of new issues to get people's support. There is no gainsaying; most of the issues were related to Abdullah Badawi's promises which are to improve the administrative system as discussed earlier. For example, in the election campaign, the government had highlighted as follows: first, promise to bring better changes in the administration as expressed in some of Abdullah Badawi's speeches. Second, exploiting the Islam Hadhari policy to foster community support (not only from the Malays but also the various ethnic groups), and to compete with the Islamic countries concept and Islamic approach by PAS, which is considered extreme by BN's leaders. Third, Abdullah Badawi's personality was highlighted as a religious, clean, and moderate leader.

Therefore, with the emphasis on the above issues in the 2004 general election, BN seems to have intercepted almost all important issues that have become major issues by opposition party in 1999 general elections (Joseph Liow 2004; Marzuki Mohamad 2004). As a result, 2004 general elections result has gave great success to the BN. BN got 90.4 percent of parliamentary seats which is the best performance for the BN since 1969. Overall, BN won 199 seats from the 219 contested parliamentary seats, while the Democratic Action Party (DAP) obtained 12 seats, PAS acquired six seats and KeAdilan (Justice Party) only captured one seat. The result shows that BN managed to get back support from society in 2004 general election, after experiencing a worse decline in the 1999 general election. In conclusion, the first phase of the Abdullah Badawi's reign he had planned and introduced several policies to improve the governance. The reform agenda has given great hope to the people as the promise similar with the people demands during the final phase of Mahathir's reign (1998-2003).

\subsection{The Emergence of Civil Disobedience}

After great victory in 2004 general election, Abdullah Badawi's position is quite comfortable as he successfully steered the economy into a higher level after suffering a serious deterioration in 1998 and 1999. For example, in 2005, Malaysia's per capita income increased from U.S. \$ 5.284 in 1990 to U.S. \$ 10.318 in 2005 . In addition, the national poverty rate decreased significantly from 22.8 percent in 1991 to 5.7 percent in 2004 (Malaysia, 2006). With good economic growth, the government can implement the policy that has been planned. Apart from economic growth, he was also praised for being more transparent and fair leader. This is because, in September 2004 Anwar Ibrahim was acquitted by the Federal Court from sodomy charges he faced in 1999 during Mahathir's reign. According to Wain (2009:299). "Most of the experts agreed that Anwar was exonerated only because Dr. Mahathir had left the scene and his successor, Prime Minister Abdullah Badawi, had made in clear he would not try to impose his will on the court". With this situation, it was good for Abdullah to reform the democratic government as he promised.

As known earlier, Malaysia is not a purely democratic country as it was labeled by some 
scholars. It is a quasi-democracy (Zakaria Ahmad, 1989), semi-democratic (Case 1993), and statist democracy (Jesudason, 1995). Therefore, as recounted above, Malaysia should be able to achieve democratization process. This is because apart from favorable prospect for economic growth, Abdullah Badawi was committed to reform in democratic governance, such as more open, transparent, improving the judicial system, reforming public service and delivery system, listening to the people, and others. This is in accordance with Dahls (1971) and Doorenspleet (2006) opinion. According to Dahl "the characteristics of democracy are freedom to form and join organizations, freedom of expression, right to vote, eligibility for public office, right of political leaders to compete for support and votes, alternative sources of information, free and fair elections and institutions for making government policies depend on votes and other expressions of preference." Meanwhile, Doorensplet state, "economic developments have an influence on democratization. His analysis shows the effect of economic development to democratization occurred drastically, especially during the third wave of democratization (1976-1989)."

Nevertheless, the process of democratization did not occur. This is because first, Abdullah Badawi did not fulfill his promise to reform. This has been proven as government is still shrouded in some corruption cases. For example Port Klang Free Zone (PKFZ). PKFZ corruption, occurs when the Kuala Dimensi Private Limited Companies, acquired PKFZ by RM95 million from Pulau Lumut Development Corporation in 1999. In 2003 Kuala Dimensi Private Limited Companies sold PKFZ to Port Klang Authority at RM 1.1 billion. The price is higher than the actual price. Further the development of PKFZ became a controversy, when the contractor appointed to develop the area Kuala Dimensi Private Limited Companies, made the cost rose from about RM4.6 billion to RM12 billion. In addition, although Malaysia's economy grew in 2004 and 2005, but in 2006 economic climate became uncertain due to the increase in global oil prices. As a result, the government cut fuel subsidy and increased oil prices and electricity rates. Then, there was rising prices and subsequently contributed to the higher cost of living. People did not agree with the government's action and this caused protests. For instance, in March 2006, Malaysia Trade Union Congress (MTUC) leaders, led workers and non-governmental organizations (NGOs) activists at Kuala Lumpur City Center (KLCC) to protest against oil price hike. The crowd at the demonstration was broken up amidst accusation that the police had used excessive force and 17 people were arrested.

Secondly, Abdullah Badawi's leadership was also overshadowed by the intervention of his family, exposed by former Prime Minister Mahathir Mohamad. These caused dissatisfaction among the citizens. Besides the family intervention, Mahathir also criticized Abdullah because he was not satisfied with some of the decisions made by Abdullah Badawi. Among them was the government reduction of the tariff for imported vehicles which can threaten the national car. Abdullah also decided to cancel the crooked bridge project and the government failed to handle economic problems. According to Mahathir, during his resignation, the economic situation was good and experienced a remarkable growth but after Abdullah took over he failed to deal with economic problem. In addition, Mahathir was not satisfied with the mainstream media in favor of Abdullah. This is because according to him the mainstream media did not report nepotism in the government.

Third, Abdullah Badawi's administration also failed to deal with racial issues (inter-faith tension). To be noted, Malaysia is a multi-racial and multi-religious country. The Malays are the main races as well as other nations such as Chinese and Indian. While the official religion is Islam, other religions such as Budhist, Christianity and Hinduism are freely to be practiced. In the second phase of his reign, the actions of Local Authorities which demolished Hindu temple at several areas in Selangor angered the non-Muslim community, especially the Indians. The action had angered the Indians not only in the local areas but most of the Indians, thus, the Hindu Right Action Force (Hindraf) protested against the government, and demanded the government to protect their rights (Johan Saravanamuttu, 2008).

Base on previous discussion, in the second phase of Abdullah Badawi's administration, he failed to fulfill his promise and failed to deal with the important issues. As a result, the citizens were dissatisfied and caused the emergence of civil disobedience. Civil disobedience began with the expression on the internet. For example, in the year 2006, there were many blogs that criticize Abdullah Badawi's leadership. The blog involved various groups. It included Dr. Mahathir (a former Prime Minister of Malaysia), Kadir Jassin (a former New Straits Times Press chief editor) and 
Ruhainie Ahmad (former members of Parliament). This situation was consistent with the Bedau (1991) statement. He states that "civil disobedience occurs with the intention of frustrating or protesting some law or policy decision of the government (or some of its officers)." In addition, the Indians through Hindraf had also repeatedly sent a memorandum to the Prime Minister because of dissatisfaction with the government's treatment of Indians. However, both the internet and memorandum had been ignored by the government. As a result, people held street demonstration. Among the biggest demonstration was that organized by the coalition for clean and fair elections known as Bersih (clean) and Hindraf.

Bersih is a combination of several NGOs and political parties who call for changes in the electoral process, in terms of clean and fair election. Bersih demonstration was held on 10 November 2007 and involved approximately 30,000 of all races. Among the Bersih's claim is reviewing the existing electoral rolls, use of indelible ink, the abolition of postal voting and fair media coverage to all political parties (Gatsiounis, 2008; Johan Saravanamuttu, 2008; Ooi Kee Beng 2008).

The Hindraf demonstration was held on 25 November 2007. Hindraf purpose was to protest several issues including the demolition of Hindu temples by local authorities. In addition, Hindraf was not satisfied about the poverty of the Indian community in Malaysia. They blamed the British government for bringing them to Malaysia and have been exploited for 150 years as plantation workers. During the rally, they marched to hand over petition to the British High Commission. The petition containing 100,000 signatures for Queen Elizabeth II, was intended to claim compensation from the British government of 27.7 trillion for the Indians in Malaysia (Ooi Kee Beng, 2008; Chin \& Wong Chin Huat 2009). Several days before demonstration, the authority had banned the rally, but it was still held and involved approximately 30,000 people (Maznah Mohamad, 2008; Ooi Kee Beng 2009).

\subsection{Civil Disobedience and Cyber Democracy}

Civil disobedience carried out through demonstration led people to receive the consequences from the authorities, such as the dispersal by tear gas, water cannons and detention under ISA. This is because the government had banned the rally even though it was held peacefully. Not only was that, in fact, the people's demand also not resolved. Further, with the situation that the peoples request are not resolved and ignored, the government dissolved the parliament on February 13, 2008 and the election was held on 12 March 8, 2011. With various issues in Abdullah Badawi's administration as discussed above, the competition in the 2008 general election was quite strong. For BN, they had to face the elections with many things that were yet to be resolved, such as economic problems, the inter-faith tension as well as claims from Bersih. In addition, Abdullah Badawi was also faced with rumors of family intervention in his administration and corruption in government. These issues were more favorable to the opposition to get community support. And this condition became more easily for the opposition, as former Prime Minister, Mahathir Mohamad who had a strong influence among the communities, had raised various criticism and attacks against Abdullah Badawi.

As a result, in $2008 \mathrm{GE}, \mathrm{BN}$ failed to win two-thirds majority of parliamentary seats. BN also lost in Kedah, Penang, Perak, Selangor, and failed to recapture Kelantan. While in the Federal Territory of Kuala Lumpur, the BN lost 10 of 11 parliamentary seats contested. Overall, from 222 contested parliamentary seats, BN won 140 seats, while opposition got 82 seats, with PKR capturing 31 seats, DAP 28 seats and PAS 23 seats (Election Commission Malaysia, 2009). For the percentage of votes, BN obtained 51.4 percent while the opposition got 48.6 percent from the total votes. Compared to the 2008 elections, BN obtained more votes in the 2004 elections, which were 63.81 percent. Thus the 2008 elections showed a sharp fall in achievement for the Barisan Nasional.

Civil disobedience affected the result of 2008 general election. Did it work on the democratization process? Base on the analysis, civil disobedience had given birth to cyber democracy. Cyber democracy occurs in virtual space as a result of community interaction via the Internet. Cyber democracy began in the United States, moving from the emergence of the cyber 
community, where people are free to talk about their activities through cyberspace. It starts with the formation of community networks such as Usenet, Newsgroups, Listserve, Mailing list, and membership in a virtual community in 1980's (Margolis \& Resnick 2000; Chadwick 2006). In reality, the political and civil rights were restricted, but virtually citizens were free to voice their opinions and to assemble without permission from the authority. This is made possible by the use of the Internet for free as promised by the Malaysian government. Further, the situation produced a variety of critical websites such as Malaysiakini, Malaysia Today, Aliran, Merdeka Review, and Rengah Sarawak (Smeltzer 2008). Furthermore, various level of the society became involved in cyberdemocracy, which is through social media. There were government supporters, oppositions, activists, NGOs and young people.

They used internet to discuss, debate, and expose a variety of important information, which relates to people whether in social, economic or political aspect. Moreover, internet was used by these groups to disseminate information to passive internet users (they are only accessing but not involved in the discussion) via e-mail, Yahoo Messenger, Facebook, Twitter, Youtube and others. As a result, it brought major changes in the 2008 election outcome as discussed earlier. Therefore, cyber democracy is a move towards democratization process in Malaysia.

Civil disobedience also created awareness among Malaysians to challenge the Abdullah Badawi's regime. For example, opposition parties namely PAS, DAP and PKR, disseminate latest political news, and also provide a special column for people, to express their dissatisfaction to the government via the party websites. In addition, the political party leaders also develop their own personal blog. The concept of their blogs are text-based, to post various events, latest news, key issues, citizens problem and the space for people to voice their views. Among the blog, were Anwar Ibrahim, Lim Kit Siang, Karpal Singh, Abdul Hadi Awang, Husam Musa and Nasharuddin Mat Isa. Interestingly, they respond very quickly to people's question and views. Therefore, citizens have opportunities to express their opinion and receive immediate feedback from the opposition. Meanwhile, the government depend more on the mainstream traditional media and did not provide a fast and clear feedback to the criticism and people opinion (Ahmad Rizal Ahmad Yusof, 2008; Smeltzer 2008).

In addition, there were plenty of political blogs and online forums that were developed by individuals and did not represent any political party. They threw their political views in many areas for the community to evaluate. The main issue discussed was the citizen's dissatisfaction with the Abdullah Badawi's administration, to the extent that these issues became a hot debate. Among the blogs that received many visitors is, Kadir Jassin, Kuda Kepang, Sang Kelembai, Raja Petra Kamaruddin, Rocky Atan, and Haris Ibrahim. In sum, civil disobedience only affects the 2008 general election, but not able to change the government and create the needed democratization process. However it has given birth to cyber democracy and created awareness among Malaysians to challenge the Abdullah Badawi's regime.

\section{Conclusion}

This paper discusses civil disobedience and its impact during Abdullah Badawi's reign. Abdullah Badawi was appointed as Prime Minister in 2003 when Dr. Mahathir stepped down as Prime Minister after 22 years of ruling the country. At first, he received great support from the community, so he managed to regain the glory for BN. In 2004 general elections, the BN achieved a great victory by winning 94 percent of the parliamentary seats contested. However, in the second phase of his administration the plans had not been fully implemented by government. As a result, civil disobedience took a toll on the 2008 general elections. In that election, the BN failed to maintain two-third majority of the parliamentary seats, and lost five states to the opposition. Nevertheless, civil disobedience only affected the 2008 general elections, but failed to change the government and create the democratization process. Although it could not change the government, it was able to give birth to cyber democracy and create awareness among Malaysians to challenge the Abdullah Badawi's regime and pursue the process of democratization in the post Mahathir's administration. 


\section{Acknowledgements}

We would like to acknowledge the valuable contributions of the following persons; Prof. Dato' Wira Dr. Mohamed Mustafa Ishak Vice Chancellor, Universiti Utara Malaysia (UUM), Prof. Dr. Noor Azizi Ismail Deputy Vice Chancellor (Research and Innovation), UUM, All the staff of the department of Research and Innovation Management Centre, UUM and last but not least The Ministry of Higher Education, Malaysia for awarding us with the FRGS Grant to carry out this research project.

\section{References}

Abdul Rashid Moten \& Tunku Mohar Mokhtar. (2006). The 2004 general elections in Malaysia: a mandate to rule. Asian Survey, 46(2): 319-340.

Ahmad Rizal Mohd Yusof. (2008, August 5-7). Pendemokrasian Internet: pengaruh komuniti elektronik dalam pilihan raya Malaysia ke 12 (Internet democratization: the influence of electronic community in Malaysian $12^{\text {th }}$ election) Proceeding of the $6^{\text {th }}$ International Malaysian Studies Conference: Engaging Malaysian Modernity 50 Years and Beyond, Kuching, Sarawak, Malaysia.

Bedau, H.A. 1991. Civil disobedience and personal responsibility for injustice. In. H.A. Bedau (Eds.). Civil disobedience in focus (pp. 49-67). London: Routledge.

Case, W. 1993. Semi democracy in Malaysia: withstanding the pressures for regime change. Pacific Affairs 66(2): 183-205.

Chadwick, A. (2006). Internet politics: state, citizens and new communication technologies. New York: Oxford University Press.

Chin, J. \& Wong Chin Huat. (2009). Malaysia's electoral upheaval. Journal of Democracy 20(3): 71-85.

Dahl, R.A. (1971). Polyarchy: participation and opposition. New Haven: Yale University Press.

Doorenspleet, R. (2006). Democratic transitions: exploring the structural sources of the fourth wave. New Delhi: Viva Books.

Election Commission Malaysia (2009). Report of the 12th General Elections 2008. Kuala Lumpur: Percetakan Nasional Malaysia.

Francis Loh Kok Wah. (2009). Old vs new politics in Malaysia. Petaling Jaya: SIRD.

Gatsiounis, I (2008). Beyond the veneer: Malaysia's struggle for the dignity and direction. Singapore: Monsoon.

Huntington, S.P. (1991). The third wave: democratization in the late twentieth century. London: University of Oklahoma Press.

Johan Saravanamuttu (2008). A tectonic shift in Malaysian politics. In Ooi Kee Beng, Johan Saravanamuttu \& Lee Hock Guan (Eds), March 8: eclipsing May 13 (pp. 33-79). Singapore: Institute of Southeast Asian Studies.

Joseph Liow (2004). A brief analysis of Malaysia's eleventh general election. UNISCI Discussion Papers. [Online] Available: www.ucm/es/BUCM/revistas/cps/16962206/articulos/UNISOHO4043300004A.PDF. (December, 1, 2008)

Jesudason, J. V. 1995. Statist democracy and the limits to civil society in Malaysia. Journal of Commonwealth and Comparative Politics 33(3): 335-356.

Malaysia (2006). The Ninth Malaysia plan 2006-2010. Kuala Lumpur: Percetakan Nasional Malaysia.

Margolis, M. \& Resnick, D. (2000). Politics as usual: the cyberspace "revolution". Thousand Oaks: Sage Publications.

Marzuki Mohamad. (2004). Malaysia's 2004 general elections: spectacular victory, continuing tensions. Kasarinlan: Philippine Journal of Third World studies 19(2): 25-53.

Maznah Mohamad. (2008). Malaysia-democracy and the end of ethnic politics?' Australian Journal of International Affairs 62(4):441-459.

Ooi Kee Beng. (2008). The opposition's year of living demonstratively. In Ooi Kee Beng, Johan Saravanamuttu \& Lee Hock Guan (Eds), March 8: eclipsing May 13 (pp. 65-32). Singapore: Institute of Southeast Asian Studies.

Ooi Kee Beng. (2009). Arrested reform: the undoing of Abdullah Badawi. Kuala Lumpur: REFSA.

Paridah Abdul Samad. (2008). Abdullah Ahmad Badawi: a new breeze in Malaysia's politics. Kuala Lumpur: Partisan Publication.

Quigley, C.N \& Bahmueller, C.F. (2001). Civitas: a framework for civic education. Calabasas, CA: Center for Civic Education.

Rawls, J. (1971). A theory of justice. Massachusetts: Belknap Press.

Sheldon, G.W. (2005). The encyclopedia of political thought. New Delhi: Viva Books.

Smeltzer, S. (2008). 'Blogging in Malaysia', Journal of International Communication 14(1): 28-45.

Wain, B. (2009). Malaysian maverick: Mahathir Mohamad in turbulent times. London: Palgrave Mcmillan. 
Zakaria Ahmad. (1989). Malaysia: quasi democracy in a divided society. In L. Diamond, J.J Linz \& S.M. Lipset (Eds). Democracy in developing country. (Asia. Vol. 3.). Boulder: Lynne Rienner. 